\section{IN MEMORY \\ OF BORIS S. LOBANOV}

PACS 01.60.+q

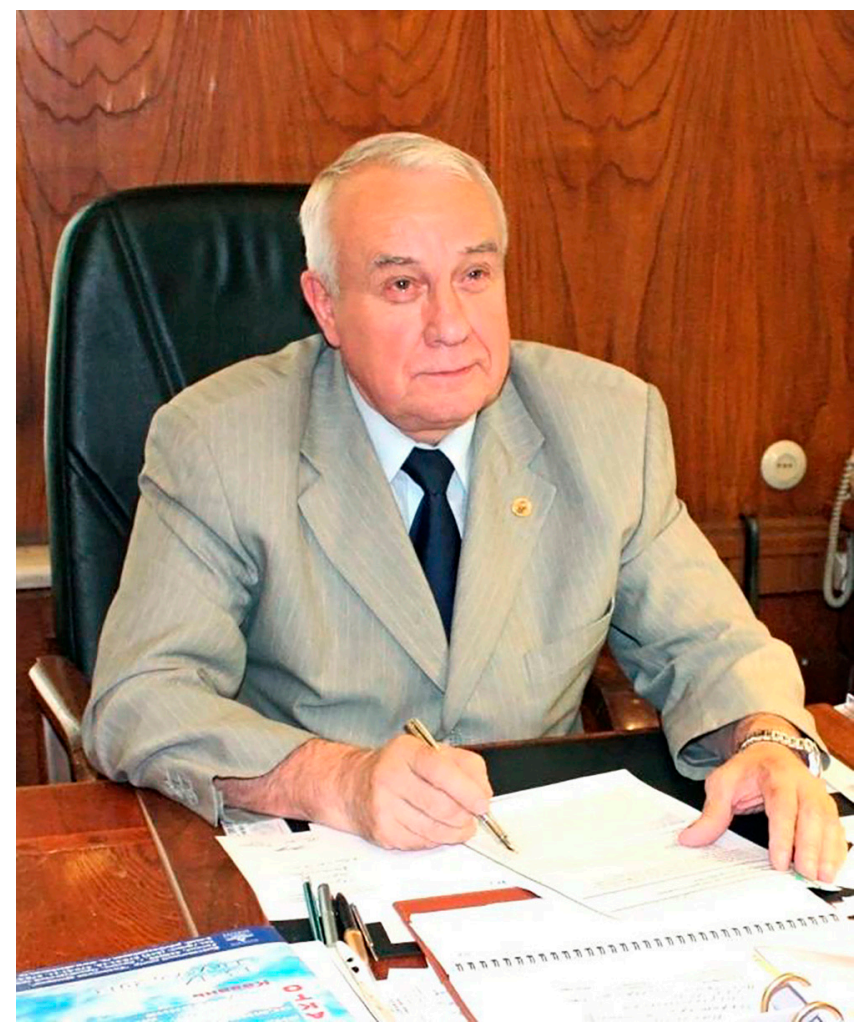

Boris Semenovich Lobanov - the Doctor of Engineering Science, the Professor, the Academician of the Russian Academy of Natural Sciences, the presidium member of the Russian Academy of Natural Sciences, the General Director and Designer of the Central Research Radiotechnical Institute named after acad. A.I. Berg, the outstanding expert in the field of special radiotechnics and the space equipment, died on March 13, 2015 in his 73th year of life after an extended illness.

Boris Semenovich was born July 31, 1942 in Krasnooktyabrsky village of the Khimki district of the Moscow region in a family of the employee of railway junction, Lobanov Semyon Ivanovich. In another month after the son's birth, his father had gone to the front. As the commander of tank turret, he participated in the Kursk salient battle and was killed in battle near Sandomir, in Poland. His Mother, Ipatova Anna Guryanovna, the inspector raising the son in the hardest conditions of military years died as a result of industrial accident in 1952.

In 1953 after 3 classes in Hovrinsky secondary school, Boris entered the Suvorov military college (SVU) in Tambov (there wasn't such SVU in Moscow). Taking into account all severity of children's barracks which was Suvorov military college by definition, the Tambov SVU was one of the best institutions of its kind in the Soviet Union. Due to certain circumstances and, first of all, thanks to the heads, people of unique qualities - the legendary General, Kapitokhin
DOI: $10.17725 /$ rensit.2015.07.102

Alexander Grigoryevich (the brigade commander in the Civil war, hero-polar explorer with I.Papanin and the hero of Sevastopol defence) and the Colonel, Neyolov Nikolay Sergeyevich (the nobleman, a graduate of Sumy Cadet Corps 1917), extremely experienced teaching personnel was selected in this place, who created a peculiar educational and sport atmosphere in this closed institution by their stringency and efficiency, a rate on collective as the main character forming force, forging smart and hard-working, morally strong, responsible and gregarious mature children from boys-pupils. Boris studied easily, with a special partiality to mathematics and physics, "plunging" into almost all sports of that time that raged in the school, without being notable among his comrades, but only with his sincerity, evenness and perseverance in solution of arising tasks. In 1960, a year prior to getting of school diploma by Boris, the TbSVU was overtaken by a destructive wave of Khruschev's reforms. It was necessary to complete his education in the junior rota in Sverdlovsk (now - Yekaterinburg), where in 1961 Boris graduated from the Sverdlovsk SVU. However, his direct military career didn't gain its development: when graduating, the relevant commission recognized him not physically qualified (short-sightedness).

In 1961, having come back home, Boris began his working career as the assembly fitter in one of the Moscow defensive enterprises. In 1962, he easily enrolled at, one of the most prestigious in those times, Ordzhonikidze Moscow Aviation Institute, the faculty of "management System, informatics and electricity industry". He got married in the first year of his study. Student's years have flown in an absolute "immersion" into the fascinating specialty "Automatic Control Systems of Aircrafts" - is in the relevant column of the diploma that Boris got in 1967 upon graduation from the MAI. Electrical and mechanical engineer Boris Semenovich Lobanov works in research organizations of the defense industry complex, in the Central Research Institute for Automation and Hydraulics, the Central High Altitude hydrometeorological observatory, the All-Russian Research Institute for Optical and Physical Measurements. He with his wife Galina brings up their daughters Anna and Nataliya in a three-room apartment of a standard house on the Sevastopolsky Avenue; a summer cottage on plot 4 acres of land near the Chekhov; round "Zaporozhets", which he repaired by his own forces.

Since 1975 - in the well-known Central Research Institute "Kometa" he participates in development, creation and operation of difficult space systems, having risen through the ranks from the leading engineer to the deputy chief designer. His work is honored by the medal "For Labour Difference" (1977). In the years of restructuring, he felt up to receive, in addition to everything, the higher 
economic education at evening department of Lomonosov Moscow State University.

Since 1991 - at the managerial work: he worked as the director of the Central Research Institute "Kometa" branch (1991-1998), the First Deputy director general of Central Research Institute "Kometa" (1998-2005). His work is honored by the RF Government prize (1999) "For development and creation of new techniques". The decree of the Russian President awarded Boris Semenovich Lobanov a rank "The honored mechanician of the Russian Federation" (2012). He has tens of awards- awards and medals, diplomas and state commendations, departmental, public, anniversary.

In 2005 B.S. Lobanov is appointed the director general of the Central Scientific-Research Radio Engineering Institute named after the academician A.I. Berg (CNIRTI named after Berg), well-known 108 Institute in the past, based in Basmanny district of Moscow in 1943 by the decree of I.V. Stalin and the decree of State Defense Committee No. 3686ss "About radio location" named AllUnion Scientific Research Institute of Radiolocation. After the founder - rear admiral, the academician of Academy of Sciences of the USSR Aksel Ivanovich Berg who was the director of his creation for the first 14 years, the institute develops the equipment for radio- electronic intelligence and radio-electronic warfare of aviation, land and space basing. The institute's destiny is difficult - there were 16 directors in 50 years after A.I. Berg. Nevertheless, within these walls a generation of radio-electronic space surveillance, electronic warfare and electronic countermeasure systems were designed; the researches were awarded with the highest prizes of the country - Lenin and State Prizes, Government Prizes. However, the years of restructuring ("perestroyka") turned into innumerable losses for the Institute: by 2005 the Institute have not been paid wages for 4 years and was on the verge of disbandment. B.S. Lobanov managed to recover wages by 2007, to return lost spaces, largely to upgrade equipment and attract young people to the Institute, having organized the basic department "Electronic warfare systems" in MIREA-MSTU. For Boris Semenovich, the Institute was - like a home, but not a source of income, he lived its life, life of the enterprise, making a great deal of national importance. With his leaving, the era of famous directors of the Central Scientific-Research Radio Engineering Institute sank into oblivion. Came the era of managers...

By 2015, the Institute is among the top three research enterprises of Roscosmos - federal authority in the sphere of space activities in the country. The Institute is provided with orders for many years ahead now.

B.S. Lobanov's activity is many-sided in his last decade. The master's thesis is defended; the doctor's defense revealed the uncommon depth and thematic broadness of researches, originality of their results is noted. Boris Semenovich - the author of more than 170 scientific works and inventions, the professor, the head of the MIREA department, the active member of several academies. Being the Presidium Member of the RussianAcademy of Natural Sciences he promoted development of the first public academy in our country.

Boris Semenovich always found time for communication with young people in his busy schedule of the almost roundthe-clock employment. With young people of the Institute, MIREA students, scholars of sponsored schools; pupils of the First Moscow Cadet Corps. B.S. Lobanov took active part in creation and development of the First Moscow Cadet Corps, being the member of its Board of trustees. Besides devotion to cadets which was the meaning of all his life ("Why do you family? Your family - cadets" - said somehow one cadet's wife. Boris annually brought together cadets-veterans in his Institute), he had a clear perception of necessity of cadet education for creation of an adequate layer of officers in army of the country. Defense capacity as the state-forming vertical, devotion to pains of his country were as breath for him, he lived with that, and that was the main motor of his life.

A huge number of people had gathered for Boris Semenovich's farewell. Boris Lobanov was buried in the Troyekurovskoye Cemetery with military honors as public state figure. There is a guard of honor near his burial ground. There is a gun carriage near his coffin, covered with the Russian tricolor. Here are relatives and friends, the management of Central Scientific-Research Radio Engineering Institute, Central Research Institute "Kometa", Almaz-Antey group of companies, VNIIOFI, MIREA, the Russian Academy of Natural Sciences, the First Moscow Cadet Corps, hundreds of friends and colleagues of the scientist and the head, dozens of wreaths from the organizations and relatives. The three times weapon salvo fire, the anthem of Russia executed by a military orchestra, funeral march of guard of honor. The final journey of Boris Semenovich came to the end with mountain of flowers on a place of his last rest.

Cherished memory about Boris Semenovich Lobanov - the talented engineer, outstanding organizer with a government thinking and a big-hearted person will be preserved in the hearts of all who ever communicate with him.

Management and collective of acad. A.I. Berg Central Scientifi esearch Radio Engineering Institute Corporation of special purpose Space Systems "KOMETA"

Acad. A.A. Raspletin Group of companies AntiAircraft Defense "ALMAZ-ANTEY" MSTU Moscow Institute of Radiotechnics,Electronics and Automation Presidium of Russian Academy of Natural Sciences D.Donskoy First Moscow Cadet Corps Moscow society of veterans TbSVU Editorial Board of RENSIT 